\title{
Mass and Energy Balance Analysis of Methanol Production Using Atmospheric CO2 Capture with Energy Source from PCMSR
}

\author{
Andang W. Harto ${ }^{1}$ and Mella Soelanda \\ ${ }^{1}$ Department of Nuclear Engineering and Engineering Physics, Faculty of Engineering, Universitas Gadjah Mada, Indonesia \\ andangftn@yahoo.com, ${ }^{1}$ andangwh@ugm.ac.id
}

\begin{abstract}
The rising of atmospheric $\mathrm{CO} 2$ concentration is the major source to global warming system. Many methods have been proposed to mitigate global warming, such as carbon penalty, carbon trading, $\mathrm{CO} 2$ sequestration, etc. However these proposed methods are usually uneconomical, i.e., these methods do not produce economic valuable substances. This paper will propose a method to absorb atmospheric $\mathrm{CO} 2$ to produce economic valuable substances such as methanol, dimethyl ether, ethylene, several hydrocarbon substances and derivatives and several graphite substances. This paper is focused on methanol production using atmospheric $\mathrm{CO} 2$ capture. The overall process is endothermic. Thus a sufficient energy source is needed. To avoid more $\mathrm{CO} 2$ emission, the energy source must not use conventional fuels. To assure the continuity of energy deliberation, nuclear energy will be used as the energy source of the process. In this paper, the Passive Compact Molten Salt Reactor (PCMSR) will be used as the energy source. The 460 MWth PCMSR is coupled with atmospheric CO2 capture, desalination, hydrogen production and methanol production facilities. The capturing $\mathrm{CO} 2$ capacity is $7.2 \mathrm{ton} / \mathrm{h}$ of atmospheric $\mathrm{CO} 2$. The valuable outputs of this system are $3.34 \mathrm{ton} / \mathrm{h}$ of $\mathrm{H} 2,34.56 \mathrm{ton} / \mathrm{h}$ of O2, $5.24 \mathrm{ton} / \mathrm{h}$ of methanol and $86.74 \mathrm{MWe}$ of excess electricity. Keywords- $\mathrm{CO}_{2}$; methanol; economic product; PCMSR
\end{abstract}

\section{Introduction}

The increasing of atmospheric $\mathrm{CO} 2$ concentration becomes the most important environmental issue recently. The increase of $\mathrm{CO} 2$ in the earth atmosphere gives the effect of global warming which in turn causes global climate change [1]. The global climate change will cause many serious problems to human civilization. The examples of serious effects global climate are several natural disasters such as flooding, drought, harvesting failure, etc. [2]. Several actions have been proposed, and some of them have been implemented. The common goal of these actions is to reduce human-made $\mathrm{CO} 2$ emission and to increase $\mathrm{CO} 2$ absorption of both naturally or human-made. Some of the examples of actions to reduce $\mathrm{CO} 2$ emission are carbon penalty to every entity who emit $\mathrm{CO} 2$ by using conventional energy resources or other emitting $\mathrm{CO} 2$ process, carbon certificate and carbon trading for every entity who able to substitute the emitting $\mathrm{CO} 2$ processes with the other processes that emit less $\mathrm{CO} 2$ [3]. The examples of actions to increase $\mathrm{CO} 2$ absorption or to limit the decreasing of $\mathrm{CO} 2$ absorption are deforestation penalty and $\mathrm{CO} 2$ sequestration.

Most of these proposed methods do not produce real economics products, so the implementation of these actions will be viewed as an economic burden of human civilization. The consequence, massive law enforcement is required to guarantee these actions to be a success. It is interesting to invent a method of atmospheric $\mathrm{CO} 2$ increasing mitigation that able to produce real economics valuable products. This will promote the global warming mitigation by natural human behavior.

\section{Basic Theory}

\subsection{Valuable substances from $\mathrm{CO}_{2}$}

The $\mathrm{CO} 2$ can be reacted with $\mathrm{H} 2$ to produce methanol $(\mathrm{CH} 3 \mathrm{OH})$ [4]. The methanol itself is a valuable substance. The methanol also can be processed to produce more valuable substance. For example, the methanol can be dehydrated to produce dimethyl ether (DME) [5]. Dimethyl ether can be dehydrated to produce ethylene [6]. Ethylene can be polymerized to produce several synthetic hydrocarbon substances. All of these substances are economically valuable and also feedstock to produce more valuable substances. Thus $\mathrm{CO} 2$ is actually can be processed to produce several economically valuable substances.

In recent technology industrial scale, $\mathrm{CO} 2$ is produced form other economically valuable substances. Production cost consideration and limiting the availability these substances limit the amount of $\mathrm{CO} 2$ production, and thus limit the number of several valuable substances produced from $\mathrm{CO} 2$. If it can be captured economically, the 
atmospheric $\mathrm{CO} 2$ will become huge and cheap $\mathrm{CO} 2$ resources to produce several economically valuable materials. The consequence, by this method the mitigation of global warming will boost economic development and will be no longer viewed as an economic burden for human civilization.

\subsection{Atmospheric $\mathrm{CO}_{2}$ Capture}

There are two types $\mathrm{CO}_{2}$ capture method. The first is $\mathrm{CO}_{2}$ capture from concentrated $\mathrm{CO}_{2}$ sources such as exhaust stack of coal or oil-fueled power plants or engines. The types of methods are relatively well established. However, these methods are not suitable to capture $\mathrm{CO}_{2}$ from diffuse sources such as vehicles or other diffuse sources in which emit far more $\mathrm{CO}_{2}$ than concentrated sources around the world. Thus the method to capture $\mathrm{CO}_{2}$ directly from earth atmosphere is far more interesting.

Stolarrof et al. propose a method to capture $\mathrm{CO}_{2}$ directly from earth atmosphere [7]. $\mathrm{CO}_{2}$ will not be utilized after capturing but will be sequestrated. However, the Stolarrof method is interesting due to the ability to capture atmospheric $\mathrm{CO}_{2}$ is a simple manner. This method will be referred I this paper.

In the Stolarrof method, atmospheric air is contacted with $\mathrm{NaOH}$ solution, and the $\mathrm{CO}_{2}$ will be captured by this following reaction [7] :

$$
2 \mathrm{NaOH}_{(\mathrm{aq})}+\mathrm{CO}_{2(\mathrm{~g})} \Rightarrow \mathrm{Na}_{2} \mathrm{CO}_{3(\mathrm{aq})}+\mathrm{H}_{2} \mathrm{O}_{(\mathrm{l})}
$$

The $\mathrm{Na}_{2} \mathrm{CO}$ is then regenerated by this following reaction [7] :

$$
\mathrm{Na}_{2} \mathrm{CO}_{3(\mathrm{aq})}+\mathrm{Ca}(\mathrm{OH})_{2(\mathrm{~s})} \Rightarrow 2 \mathrm{NaOH}_{(\mathrm{aq})}+\mathrm{CaCO}_{3(\mathrm{~s})}
$$

Thus the $\mathrm{CO}_{2}$ is trapped in solid $\mathrm{CaCO}_{3}$. In the original Stolarrof proposal, the $\mathrm{CaCO}_{3}$ is directly sequestrated. This means the overall process is costly and unsustainable because need $\mathrm{Ca}(\mathrm{OH})_{2}$ continually.

In this paper, the $\mathrm{CaCO}_{3}$ is regenerated by this following reaction :

$$
\mathrm{CaCO}_{3(\mathrm{~s})} \Rightarrow \mathrm{CaO}_{(\mathrm{s})}+\mathrm{CO}_{2(\mathrm{~g})}
$$

The $\mathrm{CaO}$ is then reacted with water to obtain $\mathrm{Ca}(\mathrm{OH})_{2}$ with the following reaction :

$$
\mathrm{CaO}_{(\mathrm{s})}+\mathrm{H}_{2} \mathrm{O}_{(\mathrm{l})} \Rightarrow \mathrm{Ca}\left(\mathrm{OH}_{2}\right)_{(\mathrm{s})}
$$

The overall process will be sustainable in term of $\mathrm{NaOH}$ and $\mathrm{Ca}(\mathrm{OH})_{2}$. However, it is useless if the $\mathrm{CaCO}_{3}$ regeneration is done in an atmospheric condition, so the $\mathrm{CO}_{2}$ is released back into the atmosphere. In this paper, the $\mathrm{CaCO}_{3}$ regeneration must be done in a reactor which supplied with hydrogen so the released $\mathrm{CO}_{2}$ will react with hydrogen to produce methanol by this following reaction [4] :

$$
\mathrm{CO}_{2(\mathrm{~g})}+3 \mathrm{H}_{2(\mathrm{~g})} \Rightarrow \mathrm{CH}_{3} \mathrm{OH}_{(\mathrm{g})}+\mathrm{H}_{2} \mathrm{O}_{(\mathrm{g})}
$$

The overall system of atmospheric $\mathrm{CO}_{2}$ capture followed by methanol synthesis, methanol dehydration,
DME dehydration and synthetic hydrocarbon synthesis is shown in Fig. 1.

\subsection{Hydrogen Production}

According to equation (4), hydrogen is needed to convert $\mathrm{CO}_{2}$ to methanol. Free hydrogen is unavailable naturally in a sufficient amount. Thus free hydrogen must be produced from naturally abundant feed materials. Hydrogen can be produced from conventional energy resources by using steam reforming method [8]. However, this method emits $\mathrm{CO}_{2}$ thus this method is not suitable to the ultimate goal of mitigation of global warming by reducing atmospheric $\mathrm{CO}_{2}$ concentration.

Hydrogen can be produced by using water as feedstock with the following reaction :

$$
\mathrm{H}_{2} \mathrm{O}_{(\mathrm{l})} \Rightarrow \mathrm{H}_{2(\mathrm{~g})}+0.5 \mathrm{O}_{2(\mathrm{~g})}
$$

The production of hydrogen from water does not emit $\mathrm{CO}_{2}$. There are several methods to produce hydrogen from water. The high-temperature steam electrolysis (HTSE) using solid oxide electrolyze cell is the efficient and lowcost method for producing hydrogen from water [9][10]. This method is used as a reference method in this paper. Fig. 2 shows the schematic diagram of solid oxide electrolyzer cell.

\subsection{Energy Consumption}

The overall reaction of capturing $\mathrm{CO}_{2}$ to become the final product of methanol is endothermic, means input energy is needed.

The reaction (1) is exothermic with $\Delta h_{0}=-109.4$ $\mathrm{kJ} / \mathrm{mole}$ of $\mathrm{CO}_{2}$ and $\Delta g_{0}=-56.1 \mathrm{~kJ} /$ mole of $\mathrm{CO}_{2}$. With the negative value of $\Delta g_{0}$, the reaction (1) is spontaneous. The reaction (2) is exothermic with $\Delta h_{0}=-5.3 \mathrm{~kJ} / \mathrm{mole}$ of $\mathrm{Na}_{2} \mathrm{CO}_{3}$ and $\Delta g_{0}=-18.2 \mathrm{~kJ} /$ mole of $\mathrm{Na}_{2} \mathrm{CO}_{3}$. Also, the reaction (2) is spontaneous.

The reaction (3) is endothermic with $\Delta h_{0}=177.99$ $\mathrm{kJ} / \mathrm{mole}$ of $\mathrm{CaCO}_{2}$. The reaction (4) is exothermic with $\Delta h_{0}=-65.3 \mathrm{~kJ} /$ mole of $\mathrm{CaO}$. The reaction (5) or methanol synthetic reaction is exothermic with $\Delta h_{0}=-102.42$ $\mathrm{kJ} /$ mole of $\mathrm{CO}_{2}$.

The reaction (6) or hydrogen production is the most energy consume reaction. Fig. 3 the energy needed to produce hydrogen from water per mole of hydrogen [11].

To produce 1 mole of methanol, 3 moles of hydrogen must be produced, 1 mole of $\mathrm{CO}_{2}$ must be captured, 1 mole of $\mathrm{Na}_{2} \mathrm{CO}_{3}$, of $\mathrm{CaCO}_{3}$ and of $\mathrm{CaO}$ must be regenerated. Thus the energy needed per mole methanol production in ideal condition is $(3 \times 250-109.4-5.3+$ $177.99-65.3-102.42) \mathrm{kJ} / \mathrm{mole}=645.79 \mathrm{~kJ} / \mathrm{mole}$. The energy needed in real condition is higher due to energy losses and the fact that not all of energy released by the exothermic reactions are recoverable. 


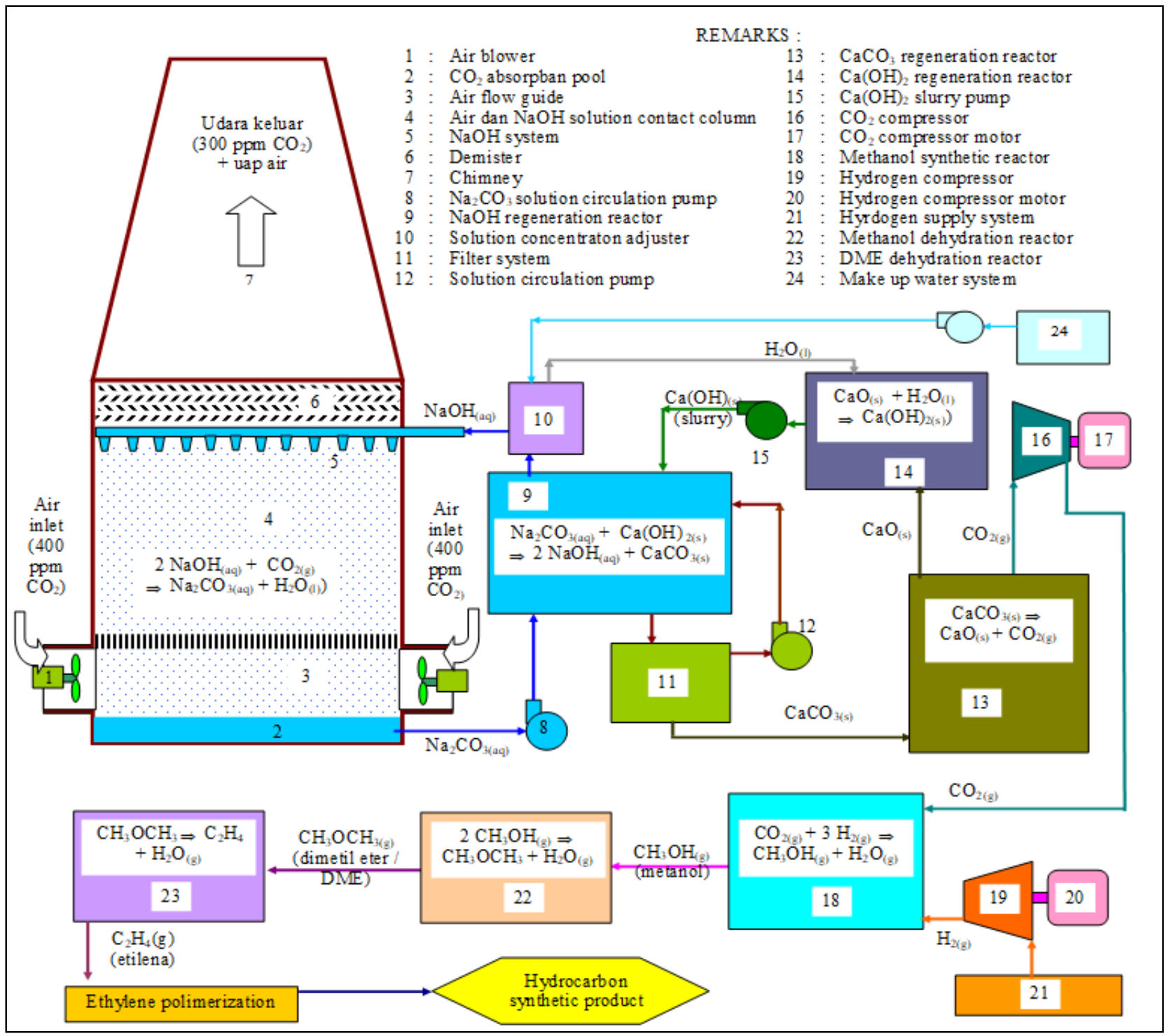

Fig. 1. The overall system of atmospheric $\mathrm{CO}_{2}$ capture followed by methanol synthesis, methanol dehydration, DME dehydration and synthetic hydrocarbon synthesis.

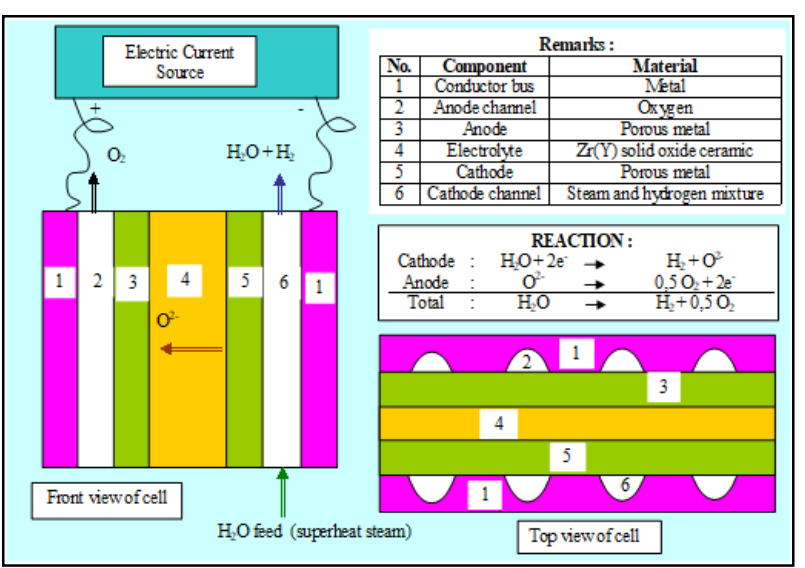

Fig. 2. Schematic diagram of Solid Oxide Electrolyze Cell

\subsection{Energy Source}

The fact that the overall reaction is endothermic means that an energy source is needed. The fossil energy sources must be excluded because of the emitted $\mathrm{CO}_{2}$ and thus contra productive with the ultimate goal to mitigate global warming by absorbing $\mathrm{CO}_{2}$.

Due to the fact that the overall process is extensive energy consume, the massive and continuous energy sources is needed. Thus nuclear energy source is the most suitable for this system.

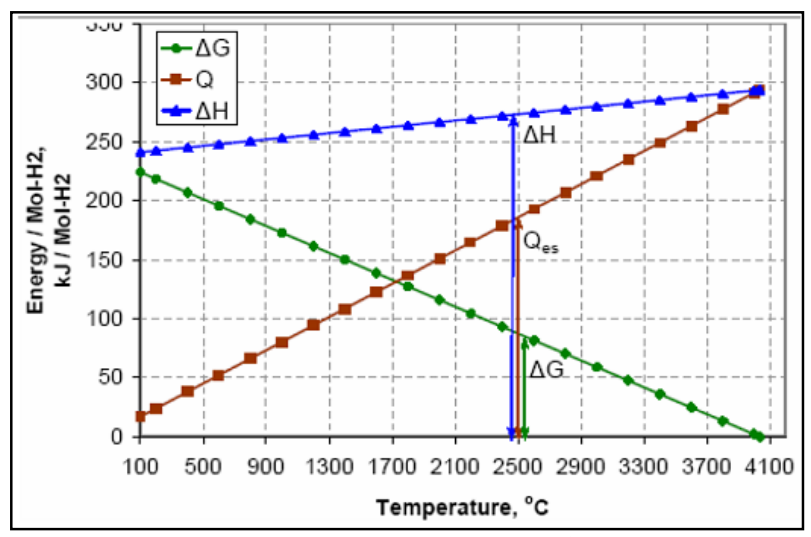

Fig. 3. Energy needed to produce hydrogen from water [11] 


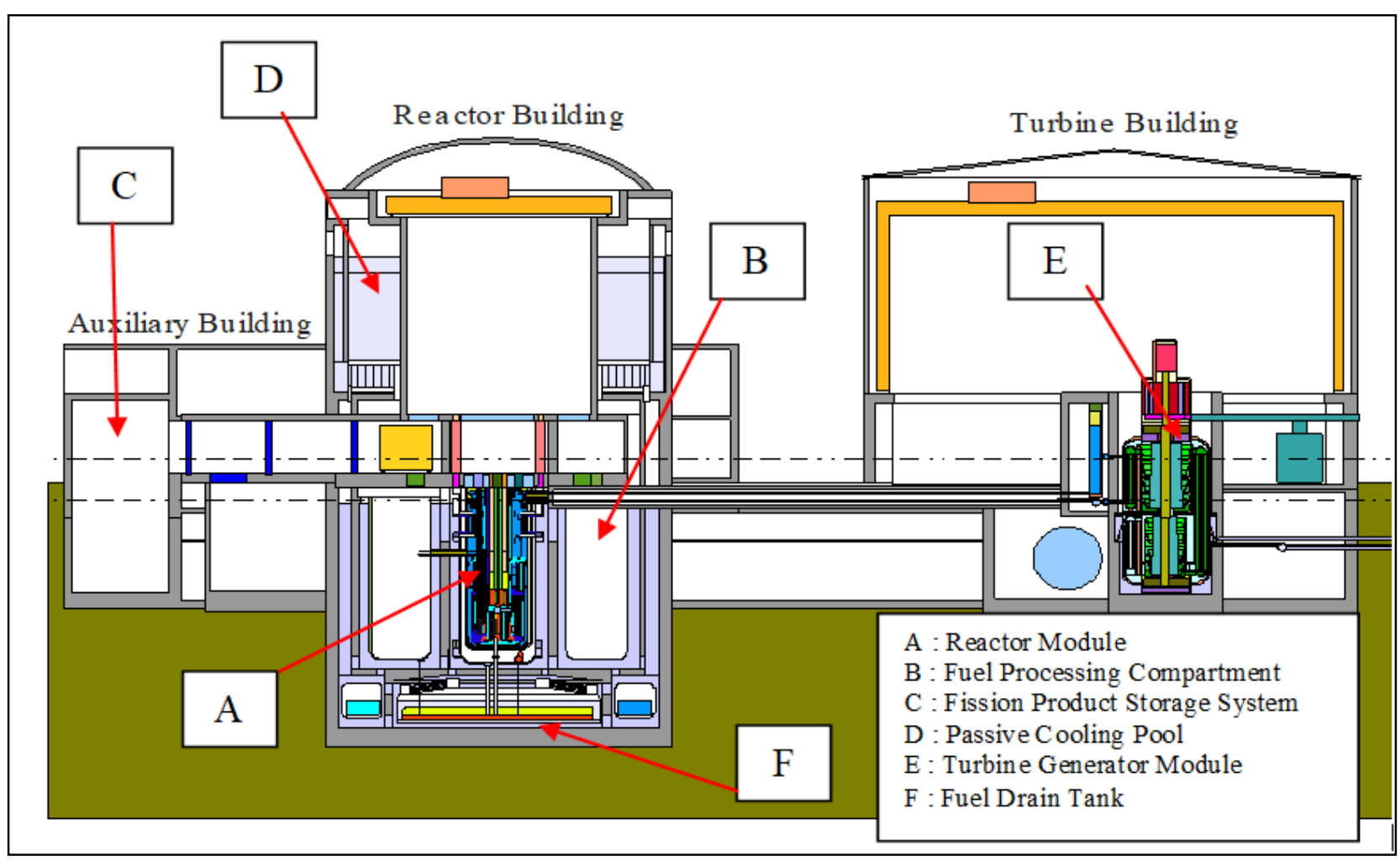

Fig. 4. The schematic diagram of PCMSR [12]

Regarding the consideration of long-term nuclear resources sustainability, the recent nuclear reactor technology that uses U-235 as fissile material is not recommended due to the natural U-235 resources scarcity.

The advanced breeder reactor utilizes more abundant fertile natural resources is more suitable. In this paper, the PCMSR (Passive Compact Molten Salt Reactor) which utilizes thorium nuclear fuel resources is applied to the energy source of the capturing $\mathrm{CO} 2$ to produce methanol process.

\subsection{PCMSR (Passive Compact Molten Salt Reactor)}

PCMSR is a variant of molten salt reactor that uses liquid fluoride salt mixture of $70 \%$ mole $\mathrm{LiF}, 29 \%$ mole $^{\mathrm{ThF}} 4$ and $1 \%$ mole $\mathrm{UF}_{4}$. The thorium is converted to fissile U233 which undergoes fission reaction and produces the reactor power. The PCMSR use graphite as moderator and LiF-NaF-KF as intermediate coolant [12]. The schematic diagram of PCMSR is shown in Fig. 4.

\section{Result and Discussion}

\section{1) Energy balance of hydrogen production}

Schematic diagram of energy balance of hydrogen production using High Temperature Steam Electrolysis using energy source from PCMSR is shown in Fig. 5. In Fig. 5, Q is heat energy, $\mathrm{W}$ is electrical energy, and $\eta$ is efficiency. The index of $\mathrm{R}$ refer to the reactor, HE refers to a heat exchanger for hydrogen production heat supply, TG refers to a turbine generator, $\mathrm{AC} / \mathrm{DC}$ refer to the electrical supply system for electrolysis process, $\mathrm{P}$ refers to pump. In this analysis, it assumed that $\eta_{\mathrm{HE}}=0.99$, $\eta_{\text {electrolizer }}=0.98, \eta_{\mathrm{AC} / \mathrm{DC}}=0.97, \eta_{\mathrm{TG}}=0.53, \eta_{\mathrm{P}}=0.70$ and $\eta_{\text {Blower }}=0.70$.

The thermal power of PCMSR is assumed to be 460 MWth. The hydrogen production capacity is set as 1.2 $\mathrm{kg} / \mathrm{s}(4.32 \mathrm{ton} / \mathrm{h})$ or $0.6 \mathrm{kmole} / \mathrm{s}=600 \mathrm{~mole} / \mathrm{s}$. The HTES is assumed to be operated at $1000{ }^{\circ} \mathrm{C}$. According to Fig. 3, $\Delta g=171 \mathrm{~kJ} / \mathrm{mole}$ of $\mathrm{H}_{2}$ and $\Delta h=251 \mathrm{~kJ} / \mathrm{mole}$ of $\mathrm{H}_{2}$ and thus $T \Delta s=\Delta h-\Delta g=(251-171) \mathrm{kJ} / \mathrm{mole}=80 \mathrm{~kJ} / \mathrm{mole}$ of $\mathrm{H}_{2}$.

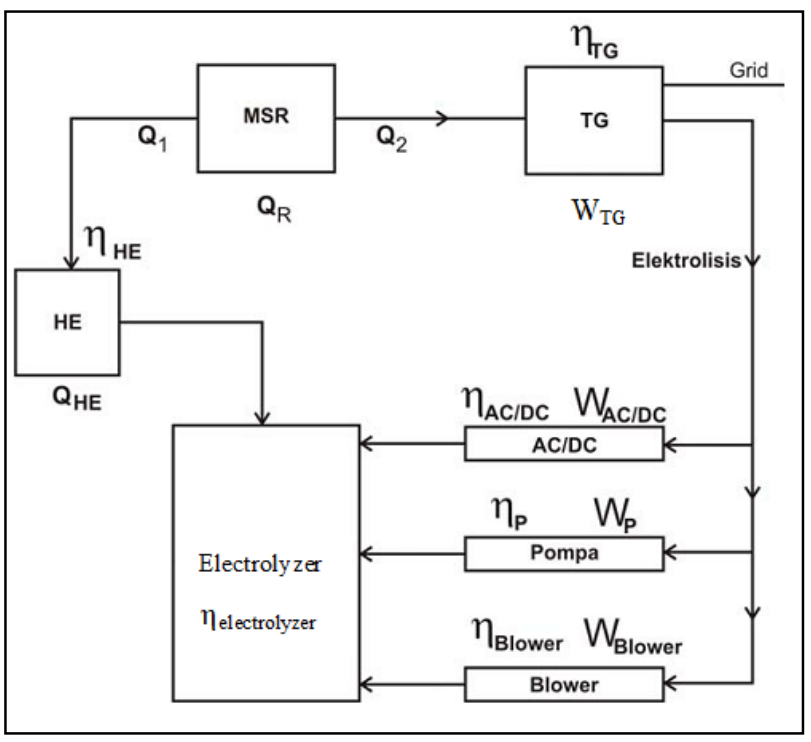

Fig. 5. Schematic diagram of energy balance of hydrogen production using High-Temperature Steam Electrolysis using energy source from PCMSR 
The $\Delta g$ component must be supplied as electrical energy. Thus the electrical power needed to supply the $\Delta g$ component is

$$
W_{E G}=\frac{\dot{m}_{\mathrm{H}_{2}} \Delta g}{\eta_{\text {electrolizer }}}=\frac{600(\mathrm{~mole} / \mathrm{s}) \times 171(\mathrm{~kJ} / \mathrm{mole})}{0.98}=104 \mathrm{MWe}
$$

The electrical energy also must be supplied to feed heater pump, recirculation water pump and gas mixture blower. The calculated overall water pumping power is small, i.e., $0.4 \mathrm{kWe}$ and the calculated blower power is 2 MWe. Thus the total electrical power to be supplied for overall electrolyze process is

$$
\begin{aligned}
W_{E} & =\frac{W_{E G}}{\eta_{A C / D C}}+\frac{W_{P}}{\eta_{P}}+\frac{W_{\text {blower }}}{\eta_{\text {blower }}}=\left(\frac{104}{0,97}+\frac{0.0004}{0.7}+\frac{2}{0.7}\right) \mathrm{MWe} \\
& =110.36 \mathrm{MWe}
\end{aligned}
$$

The $T \Delta s$ component must be supplied as heat energy from the reactor. The electrical energy loss in electrolyzer will become heat energy, and thus the thermal power to be supplied to reactor is

$$
\begin{aligned}
Q_{E G} & =\frac{\dot{m}_{H_{2}} T \Delta s}{\eta_{H E}}-\left(1-\eta_{\text {electrolizer }}\right) W_{E G} \\
& =\frac{600(\mathrm{~mole} / \mathrm{s}) \times 80(\mathrm{~kJ} / \mathrm{mole})}{0.99}-(1-0.98) \times 104 \mathrm{MWth} \\
& =48.48 \mathrm{MWe}-2.1 \mathrm{MWth}=46.38 \mathrm{MWth}
\end{aligned}
$$

Heat also must be supplied to evaporate the feed water. To produce $0.6 \mathrm{kmole} / \mathrm{s}$ of hydrogen, $0.6 \mathrm{kmole} / \mathrm{s}$ or 10.8 $\mathrm{kg} / \mathrm{s}$ of water is needed. The heat of evaporation of water is $2400 \mathrm{~kJ} / \mathrm{kg}$ of water. Thus the evaporation heat needed to produce $0.6 \mathrm{kmole} / \mathrm{s}$ of hydrogen is

$$
Q_{\text {evap }}=\frac{\dot{m}_{H_{2} O} \Delta h_{\text {evap }}}{\eta_{H E}}=\frac{10.8(\mathrm{~kg} / \mathrm{s}) \times 2400(\mathrm{~kJ} / \mathrm{kg})}{0.99}=26.18 \mathrm{MWth}
$$

The total thermal power to be supplied by reactor to produce $0.6 \mathrm{kmole} / \mathrm{s}$ of hydrogen is

$$
Q_{1}=Q_{E G}+Q_{\text {evap }}=46.38 \mathrm{MWth}+26.18 \mathrm{MWth}=72.56 \mathrm{MWth}
$$

The PCMSR has the thermal power $Q_{R}=460 \mathrm{MWth}$ and the overall turbine-generator efficiency of 0.53 . A part of this thermal power must be supplied to the hydrogen production system, i.e., $Q_{1}=72.56 \mathrm{MWth}$. Thus the thermal power supplied to the turbine system is

$$
Q_{2}=Q_{R}+Q_{1}=460 \mathrm{MWth}+72.56 \mathrm{MWth}=387.44 \mathrm{MWth}
$$

The electrical output of turbine system is therefore

$$
W_{T G}=\eta_{T G} Q_{2}=(0.53 \times 387.44) \mathrm{MWe}=205.34 \mathrm{MWe}
$$

A part of the turbine electrical output power must be supplied to the hydrogen production system, i.e. $W_{E}=110.36 \mathrm{MWe}$. Thus the turbine still produces extra electrical power of

$$
W_{E X}=W_{T G}-W_{E}=(205.34-110.36) \mathrm{MWe}=94.98 \mathrm{MWe}
$$

\section{2) Energy balance of atmospheric $\mathrm{CO}_{2}$ capture}

The atmospheric $\mathrm{CO}_{2}$ capture system is assumed to be designed capture $2 \mathrm{~kg} / \mathrm{s}(7.2 \mathrm{ton} / \mathrm{h})$ or $45.45 \mathrm{moles} / \mathrm{s}$ of $\mathrm{CO}_{2}$. The ambient air inlet is assumed to contain $400 \mathrm{ppm}$ of $\mathrm{CO}_{2}$. The capture system is assumed able to reduce the $\mathrm{CO}_{2}$ content to become $300 \mathrm{ppm}$ as the air flows out from the capture system. This means the mass flow rate of air is 20 ton/s.

To capture $45.45 \mathrm{~mole} / \mathrm{s}$ of $\mathrm{CO}_{2}, 45.45 \mathrm{moles} / \mathrm{s}$ of $\mathrm{Na}_{2} \mathrm{CO}_{3}, \mathrm{CaCO}_{3}$ and $\mathrm{CaO}$ must be regenerated. The energy released from the exothermic reaction of the capturing $\mathrm{CO}_{2}$ cycle is assumed to be unrecoverable. Thus the energy needed for capturing $\mathrm{CO}_{2}$ process cycle is equal to the energy needed for the endothermic reaction of this cycle, i.e., reaction (3). The energy is supplied in the form of heat energy. It is assumed that the heat energy is supplied via an electrical heater, which the electricity is supplied by the extra electrical power of the PCMSR turbine system. The efficiency of electrical heater is assumed to be 0.98 . The electrical power to be supplied for reaction (3) is :

$$
\begin{aligned}
W_{3} & =\frac{\dot{m}_{\mathrm{CaCO}_{3}} \Delta h_{3}}{\eta_{\text {heater }}}=\frac{45.45(\mathrm{~mole} / \mathrm{s}) \times 177.99(\mathrm{~kJ} / \mathrm{mole})}{0.98} \\
& =8.26 \mathrm{MWe}
\end{aligned}
$$

The electrical energy also must be supplied for air blower and slurry pumps. The pumping powers are small. The calculated pumping power of $\mathrm{NaOH}$ solution is 0.67 $\mathrm{kWe}$. The calculated pumping power of $\mathrm{Na}_{2} \mathrm{CO}_{3}$ solution is $0.67 \mathrm{kWe}$. The calculated pumping power of $\mathrm{NaOH}$ $\mathrm{CaCO}_{3}$ slurry is $1 \mathrm{kWe}$. The calculated pumping power of $\mathrm{CaCO}_{3}$ slurry is $0.68 \mathrm{kWe}$. The calculated pumping power of $\mathrm{CaO}$ slurry is $0.45 \mathrm{kWe}$. The calculated pumping power of $\mathrm{Ca}(\mathrm{OH})_{2}$ slurry is $0.64 \mathrm{kWe}$. The calculated pumping power of $\mathrm{H}_{2} \mathrm{O}$ make up is $0.22 \mathrm{kWe}$. The calculated air blower power is $2.67 \mathrm{~kW}$. Thus the overall air blower pumping power of the capturing $\mathrm{CO}_{2}$ cycle is $7.00 \mathrm{kWe}$.

Electrical energy also must be supplied for the operation of mixer agitators in $\mathrm{Na}_{2} \mathrm{CO}_{3}$ regeneration reactor, $\mathrm{CaCO}_{3}$ regeneration reactor, and $\mathrm{CaO}$-water reactor. The calculated mixer agitator power of $\mathrm{Na}_{2} \mathrm{CO}_{3}$ reactor is $18.33 \mathrm{kWe}$. The calculated mixer agitator power of $\mathrm{CaCO}_{2}$ regeneration reactor is $30 \mathrm{kWe}$. The calculated mixer agitator power of $\mathrm{CaO}$-water reactor is $3.55 \mathrm{MWe}$. Thus the total mixer agitator power is $46.88 \mathrm{kWe}$.

Therefore, the total electrical power to be supplied to the atmospheric $\mathrm{CO}_{2}$ capture system is

$$
\begin{aligned}
W_{C} & =W_{3}+W_{\text {pupm }}+W_{\text {agitator }} \\
& =(8.26+0.007+0.047) \mathrm{MWe}=8.32 \mathrm{MWe}
\end{aligned}
$$

\section{3) Energy balance of methanol synthesis}

The methanol synthesis reaction (reaction (3)) is an exothermic reaction. The energy released is assumed to be unrecoverable. Thus it is no energy needed to supply the reaction (3). However, the reaction (3) needs pressurization until $300 \mathrm{MPa}$. Thus both of $\mathrm{H}_{2}$ and $\mathrm{CO}_{3}$ must be compressed. The electrical energy supply needed for $\mathrm{H}_{2}$ and $\mathrm{CO}_{2}$ compression.

The calculated compressor power for $\mathrm{CO}_{2}$ compression is $0.17 \mathrm{~kW}$. The calculated compressor power for $\mathrm{H}_{2}$ compression is $5.58 \mathrm{~kW}$. Thus the total electrical power must be supplied for compressor system is 


$$
W_{\text {compressor }}=5.75 \mathrm{kWe}
$$

4) Overall energy and material balance

The total electrical power needed for overall process is

$$
\begin{aligned}
W_{\text {process }} & =W_{E}+W_{C}+W_{\text {compressor }}=(110,36+8.23+0.00575) \mathrm{MWe} \\
& =118.6 \mathrm{MWe}
\end{aligned}
$$

Therefore the surplus of electrical power is

$$
W_{\text {surplus }}=W_{T G}-W_{\text {process }}=(205.34-118.6) \mathrm{MWe}=86.74 \mathrm{MWe}
$$

The surplus electrical power can be supplied to commercial electric consumers or commercial grid.

This atmospheric $\mathrm{CO}_{2}$ capture system is assumed to have a capturing capacity of $7.2 \mathrm{ton} / \mathrm{h}(45.45 \mathrm{moles} / \mathrm{s})$ of $\mathrm{CO}_{2}$. All of the captured $\mathrm{CO}_{2}$ is converted to methanol. Thus according to reaction (5), the production capacity of methanol is $45.45 \mathrm{~mole} / \mathrm{s}$ or $5.24 \mathrm{ton} / \mathrm{h}$ of methanol.

To produce $45.45 \mathrm{~mole} / \mathrm{s}$ of methanol, according to reaction (5), $3 \times 45.45 \mathrm{~mole} / \mathrm{s}=136.35 \mathrm{~mole} / \mathrm{s}$ oh hydrogen is needed. However, the hydrogen production capacity of the HTSE system powered by 460 MWth PCMSR is $600 \mathrm{moles} / \mathrm{s}$ of hydrogen. Thus there is an excess hydrogen production of $(600-136.35) \mathrm{mole} / \mathrm{s}=$ $463.65 \mathrm{~mole} / \mathrm{s}$. The $463.65 \mathrm{~mole} / \mathrm{s}$ or $3.34 \mathrm{ton} / \mathrm{h}$ of the excess can be considered as the commercial hydrogen product.

According to reaction (6), the HTSE with a production capacity of $600 \mathrm{moles} / \mathrm{s}$ of hydrogen produces $0.5 \times 600$ moles $/ \mathrm{s}=300 \mathrm{moles} / \mathrm{s}$ of oxygen by-product. The 300 mole/s or 34.56 ton/h of the by-product can also consider as the commercial oxygen product.

\section{Summary}

It can be summarized that the global warming mitigation is not always an economic burden for human civilization. It is possible to mitigate global warming as well as produce several economics valuable products from this mitigation action. The atmospheric $\mathrm{CO}_{2}$ capture is the endothermic reaction in overall. Thus the key to this process to be a success is the availability of the abundant, cheap and not $\mathrm{CO}_{2}$ emitter energy sources. The MSR that utilizes abundant thorium resources is the prominent candidate for the energy source of this system. The analysis has been performed for 460 MWth PCMSR which is coupled with atmospheric $\mathrm{CO}_{2}$ capture, desalination, hydrogen production and methanol production facilities. For the capturing $\mathrm{CO}_{2}$ capacity of 7.2 ton/h of atmospheric $\mathrm{CO}_{2}$, this system can produce valuable outputs of 3.34 ton $/ \mathrm{h}$ of $\mathrm{H}_{2}, 34.56$ ton/h of $\mathrm{O}_{2}, 5.24 \mathrm{ton} / \mathrm{h}$ of methanol and 86.74 MWe of excess electricity.

The results showed that mussel shells contain $14.15 \% \mathrm{CaO}$. The optimum yield was $95.12 \%$ which was achieved at $\mathrm{NaOH}$ concentration of $30 \%$ and the catalyst amount of $15 \%$. The biodiesel produced was fulfilled the national standards and had a better quality compared to the conventional homogeneous catalyst. The GC-MS analysis showed that the biodiesel containing methyl ester with the largest component was methyl oleic (61.39\%).

\section{References}

1. US EPA, Climate Change Science Overview, US Environmental Protection Agency (US EPA), 14 June 2012.

2. W. Cramer, et al., Executive summary, in Chapter 18: Detection and attribution of observed impacts (archived 18 October 2014), pp.982-984, in IPCC AR5 WG2 A 2014

3. R.N. Stavins (2007). "A U.S. Cap-and-Trade System to Address Global Climate Change" . The Hamilton Project. Retrieved 2014-07-26.

4. C.A. Huff, M.S. Stanford, J. Am. Chem. Soc 133 (45), 18122-18125 (2011)

5. L.C.L.A. Jamshidi, C.M.B.M. Barbosa, L. Nascimento, J.R. Rodbari, Journal Chemical Engineering and Process Technology 4, 5 (2013)

6. S.T. Hussain, ${ }^{*}$ M. Mazhar, S. Gul, K.T. Chuang, $\dagger$ and A.R. Sanger, B. Kor. Chem. Soc 27 (2006)

7. J.K. Stolaroff, et.al., Environ. Sci. Technol 42, 2728 -2735 (2008)

8. G. Collodi, F. Wheeler, Hydrogen Production via Steam Reforming with $\mathrm{CO}_{2}$ Capture, Milan, Italia, 2009*

9. L. Mingyi, Y. Bo, X. Jingming, C. Jing, J. Power. Sources 177, 493-499 (2008)

10. J. E. O'Brien, C. M. Stoots, J. S. Herring, M. G. McKellar, E. A. Harvego, M. S. Sohal, K. G. Condie, High Temperature Electrolysis for Hydrogen Production from Nuclear Energy - Technology Summary, The INL is a U.S. Department of Energy National Laboratory, February 2010

11. Nuclear Options for Hydrogen and Hydrogen Based Liquid Fuel Production, MIT Report : MIT-NES-TR001, September 2003.

12. A.W. Harto, International Journal of Nuclear Energy Science and Technology 9 (2015)

13. M. Carolina, A. W. Harto, Kusnanto, Pengaruh Variasi Tekanan Operasi Dan Recycling Ratio Terhadap Efisiensi Produksi Hidrogen Pada Molten Salt Reactor (MSR) Dengan Sistem HighTemperature Electrolysis (HTE) Bentuk Planar Cell, Prosiding Seminar Nasional ke-17 Teknologi dan Keselamatan PLTN Serta Fasilitas Nuklir Yogyakarta, 01 Oktober 2011 (in Bahasa Indonesia) 